\title{
Short-Term Analysis of Human Dental Pulps After Direct Capping with Portland Cement
}

\author{
Antonio Vinicius Holanda Barbosa, ${ }^{1, *}$, Gerhilde Callou Sampaio ${ }^{2}$, Fábio Almeida Gomes ${ }^{1}$, \\ Daniel Pinto de Oliveira ${ }^{3}$, Diana Santana de Albuquerque ${ }^{1}$ and Ana Paula Veras Sobral ${ }^{2}$
}

\author{
${ }^{I}$ Department of Endodontics, School of Dentistry of Pernambuco, University of Pernambuco; ${ }^{2}$ Department of Oral \\ Pathology, School of Dentistry of Pernambuco, University of Pernambuco and ${ }^{3}$ Department of Endodontics, School of \\ Dentistry of Maceió, Federal University of Alagoas, Brazil
}

\begin{abstract}
This study evaluated the short-term response of human pulp tissue when directly capped with Portland cement. In this series of cases, twenty human third molars that were scheduled for extraction were used. After cavity preparation, pulp exposure was achieved and Portland cement pulp capping was performed. Teeth were extracted after 1, 7, 14 and 21 days following treatment and prepared for histological examination and bacterial detection. Each group had 5 teeth. The results were descriptively analysed. Dentin bridge formation was seen in two teeth with some distance from the material interface (14 and 21 days). Soft inflammatory responses were observed in most of the cases. Bacteria were not disclosed in any specimen. PC exhibited some features of biocompatibility and capability of inducing mineral pulp response in short-term evaluation. The results suggested that PC has a potential to be used as a less expensive pulp capping material in comparison to other pulp capping materials.
\end{abstract}

Key Words: Biocompatibility, endodontics, Portland cement, pulp therapy.

\section{INTRODUCTION}

Preservation of pulp vitality during restorative procedures is a mater of concern in operative dentistry [1]. Some authors have demonstrated that pulp alterations under different restorative materials were related to the presence of bacteria from microleakage $[2,3]$. Besides, the major cause of failure in pulp capping treatment has been attributed to bacterial contamination rather than the irritant properties of capping materials. If this hypothesis is valid, pulp healing could be expected if a material maintains the seal against microleakage [4]. Studies have showed that calcium hydroxide is not the only material capable of stimulating reparative dentin deposition [5] or dentin bridge formation [6]. The formation of dentin bridges is an intrinsic response of the exposed pulp in the absence of bacteria $[7,8]$.

Over the last years, studies have compared healing effects and the composition of PC with those of Mineral trioxide Aggregate (MTA). Regarding the healing effects, it was observed that osteoblast-like cells had similar growth and matrix formation when growing on set PC [9], while other authors noted that $\mathrm{PC}$ allowed dentin bridge formation after pulpotomy on dogs [10] and induced calcite crystal granulations deposition when placed in dentin tubes that were implanted subcutaneously in rats [11]. Moreover, it has been demonstrated that PC and MTA have a similar effect on pulp

*Address correspondence to this author at the Av. Fernando Simões Barbosa, 374/1001, Boa Viagem - Recife - PE, 51020-390, Brazil; Tel: 5581 3328-1832; 5582 9999-9290; Fax: 55813328 1832;

E-mail: holanda76@hotmail.com cells when used as a direct pulp-capping material in rats [7] as well as comparable antibacterial activity [12]. Such similarities in healing effects induced by these cements may be related to the similarities in their composition. PC has major ingredients in common with MTA such as calcium phosphate, calcium oxide, and silica. MTA also contains bismuth oxide, which increases its radiopacity and is absent in PC $[12,13]$. However, because of the low cost of the cement, it is reasonable to consider PC as a possible substitute for MTA in endodontic applications.

The purpose of this study was to evaluate short-term pulp response after PC application on exposed pulps of human teeth.

\section{MATERIALS AND METHODOLOGY}

\section{Tooth Selection}

Teeth were obtained from seven patients from the Semiology Clinic of the School of Dentistry of the University of Pernambuco. Sample consisted of twenty noncarious human third molars which were previously scheduled for extraction for orthodontic reasons. The patients ages ranged from 19 to 31 years (mean age $=24.8$ years) for both genders. The patients signed consent forms after receiving a thorough explanation about the experiment, clinical procedures and possible risks. The patients were asked to read and sign a consent form allowing the clinical procedure. Both, the consent form and the research project were approved by the Ethical Committee (protocol178/03) from the University of Pernambuco, Brazil. 


\section{Cavity Preparation and Pulp Exposure}

Local or regional anesthesia was obtained using $2 \%$ mepivacaine (DFL, São Paulo, SP, Brazil). A dental dam was used to isolate the teeth during the treatment. Before cavity preparation, the teeth were cleaned with prophylactic paste.

Class I cavities were prepared using new diamond bur (\#1015 - KG Sorensen, São Paulo, SP, Brazil) at high speed, under copious air/distilled water-cooling. The pulpal floor was extended $0.5 \mathrm{~mm}-1 \mathrm{~mm}$ from the pulp, based on a previous radiographic examination. Pulp exposures were obtained with a diamond bur $(1,2 \mathrm{~mm}$ diameter - KG Sorensen, São Paulo, SP, Brazil) at high speed and under water. Bleeding control was achieved using a sterile saline solution and sterilized cotton pellets. A new bur was used for each tooth.

\section{Material Placement}

Portland cement (CP II - F32, ITAPESSOCA AGROINDUSTRIAL S.A., Goiânia, PE, Brazil) was mixed with distilled water to achieve the desired consistency. PC paste pulp capping was performed and the cavities were sealed with glass ionomer cement (DFL, São Paulo, SP, Brazil). Teeth were extracted after $1,7,14$ and 21 days following pulp capping treatment, and assigned into four subgroups according to the time of extraction. Each group had 5 specimens $(n=5)$ resulting in a sample with 20 teeth.

\section{Histological Preparation}

Following postoperative intervals of 1, 7, 14 and 21 days, the teeth were extracted, and the apical third of the root was removed in order to facilitate formalin penetration and fixation (10\% buffered formalin solution). Demineralization was obtained with 5\% nitric acid after 4-5 weeks. Specimens were paraffin embedded and three- $\mu \mathrm{m}$ sections were obtained, which were stained with Hematoxylin-Eosin and the Brown \& Hopps technique [14]. An extracted tooth with necrotic and infected pulp was used as a control for the Brown \& Hopps technique to demonstrate the presence of bacteria.

\section{Evaluation Criteria}

The sections were blindly evaluated by a pathologist according to the criteria previously established (Cox et al. [4], Cox et al. [15] and Akimoto et al. [16]) and described in Table 1.

\section{Statistical Analysis}

The data were analyzed by descriptive statistics according to the features observed in each experimental group.

\section{RESULTS}

The values related to inflammatory cell response, soft tissue organization, dentin bridge formation and bacterial staining are summarized in Table 2. After 1 day, no dentin bridge formation was observed in any of the 5 teeth in this group. Inflammatory cell response ranged from soft to mild (Fig. 1A). Pulp tissue located below the exposure $(1,2 \mathrm{~mm}$ diameter) was generally disorganized and contained congested blood vessels.

Table 1. Scores Used for Histological Finds Based on Cox et al. [4], Cox et al. [15] and Akimoto et al. [16] Criteria

\begin{tabular}{|c|c|}
\hline 1 & None or a few scattered inflammatory cells present in the pulp beneath the exposure site \\
\hline 3 & Severe inflammatory lesion appearing as an abscess or dense infiltrate involving one third or more the coronal pulp \\
\hline 4 & Completly necrotic pulp \\
\hline 1 & Normal or almost normal tissue morphology below the exposure site and throughout the pulp \\
\hline 2 & Lack of normal tissue morphology below the exposure site, with deeper pulp tissue appearing normal \\
\hline 3 & Loss of general pulp morphology and cellular organization below the exposure site \\
\hline 4 & Necrosis in at the coronal third of the pulp \\
\hline 3 & No evidence of any dentin tissue formation in any of the tissue sections \\
\hline Scores & Bacterial Staining \\
\hline 1 & Absence of bacterial staining in any section \\
\hline 2 & Positive bacterial staining reaction along the cavity walls or within the cut dentin tubules \\
\hline 3 & Positive bacterial staining reaction within the dental pulp \\
\hline
\end{tabular}


No dentin bridge formation was observed in any of the 5 teeth in this group after 7 days. Inflammatory cell response was absent in all cases and pulp tissue disorganized and congested blood vessels were observed in one specimen (4G2) below the exposure area (Fig. 1B) while $2 \mathrm{G} 2$ specimen exhibited concentrated collagen fibers (Fig. 1C).

Table 2. The Absolute Values for Inflammatory Cell Response, Soft Tissue Organization, and Dentin Bridge Formation and Bacterial Staining. These Values are Based on Cox et al. [4], Cox et al. [15] and Akimoto et al. [16] Criteria Referred on Table 1

\begin{tabular}{|c|c|c|c|c|}
\hline Specimens & ICR & STO & DBF & BS \\
\hline $1 \mathrm{G} 1$ & 1 & 1 & 3 & 1 \\
\hline $2 \mathrm{G} 1$ & 1 & 1 & 3 & 1 \\
\hline $3 \mathrm{G} 1$ & 1 & 1 & 3 & 1 \\
\hline $4 \mathrm{G} 1$ & 1 & 1 & 3 & 1 \\
\hline $5 \mathrm{G} 1$ & 1 & 1 & 3 & 1 \\
\hline $1 \mathrm{G} 2$ & 1 & 1 & 3 & 1 \\
\hline $2 \mathrm{G} 2$ & 1 & 1 & 3 & 1 \\
\hline $3 \mathrm{G} 2$ & 1 & 1 & 3 & 1 \\
\hline $4 \mathrm{G} 2$ & 1 & 3 & 3 & 1 \\
\hline $5 \mathrm{G} 2$ & 1 & 1 & 3 & 1 \\
\hline $1 \mathrm{G} 3$ & 1 & 2 & 3 & 1 \\
\hline $2 \mathrm{G} 3$ & 1 & 2 & 2 & 1 \\
\hline $3 \mathrm{G} 3$ & 1 & 2 & 3 & 1 \\
\hline $4 \mathrm{G} 3$ & 1 & 3 & 3 & 1 \\
\hline $5 \mathrm{G} 3$ & 1 & 2 & 3 & 1 \\
\hline $1 \mathrm{G} 4$ & 1 & 2 & 3 & 1 \\
\hline $2 \mathrm{G} 4$ & 1 & 2 & 3 & 1 \\
\hline $3 \mathrm{G} 4$ & 1 & 2 & 2 & 1 \\
\hline $4 \mathrm{G} 4$ & 1 & 2 & 3 & 1 \\
\hline $5 \mathrm{G} 4$ & 1 & 2 & 3 & 1 \\
\hline
\end{tabular}

ICR - Inflammatory cell response; STO - Soft tissue organization; DBF - Dentinal bridge formation; BS - Bacterial staining; $\mathrm{G}$ - Group.

After 14 days only one specimen (2G3) of this group exhibited a dentin bridge; however, this bridge was found at some distance from interface pulp-capping material interface (Fig. 1D). Inflammatory cell response was absent in all cases, but pulp tissue below the exposure area was generally disorganized and contained congested blood vessels.

Tissue under the exposure site presented normal pulp tissue characteristics after 21 days, with new odontoblastlike cells beneath the pulp-PC interface. In this period, one specimen exhibited reparative dentin. In the teeth exhibiting no dentin bridges formation, the pulp tissue showed no changes in morphology, and inflammatory cell response was absent in all cases. Area of collagenic fiber deposition was observed in one specimen (Fig. 1E).

Brown \& Hopps technique revealed no bacteria in any section of teeth specimens (Fig. 1F).

\section{DISCUSSION}

The main aim of this investigation was to assess the short-term response of human pulps capped with PC. This was the first time that the use of PC on human pulps was tested. PC has demonstrated biocompatibility as much acceptable as MTA when applied in deep cavities in animal teeth [10]. Based on the supposition that effective sealing is more important than capping material properties, it was observed partial bridges only in teeth with problems in the coronal sealing indicating that microorganism's presence was responsible for problems in the healing process [10].

Some authors reported that the initial control of pulpal bleeding was the most critical biologic and clinical issue [16]. One approach to determine the best material used for the initial bleeding control during direct pulp capping would involve short-term histological analysis of materials used as direct pulp capping agents, such as PC and MTA. In our study, bleeding was not detected after PC application. This evidence could indicate an acceptable property of PC considering the fact that the presence of a blood clot between capping material and pulp tissue may jeopardize pulp repair and attract microorganisms, leading to infection [17]. Moreover, as restorative procedures may have a significant influence on the effectiveness of pulp capping and bleeding can compromise the efficacy and durability of adhesion $[18,19]$, the use of PC as direct pulp capping material could ensure proper adhesion of adhesive systems or glass ionomer cements, which in turn could avoid bacterial contamination from any possible microleakage after either shortor longterm.

The biological reaction of the pulp tissue to PC was satisfactory, and the tissues demonstrated that the material is not irritating. Inflammatory cells of the first day were always confined to the area straightly below to the exposure, probably because of the procedure itself. Absence of regular pulp morphology and cellular organization below the exposure site were detected in two cases $(4 \mathrm{G} 2,4 \mathrm{G} 3)$.

The mechanisms of action of MTA and PC are similar. As both materials have calcium hydroxide. The reaction of calcium from calcium hydroxide with carbon dioxide from the pulp tissue produces calcite crystals [10] when any of these materials is used [20].

An important finding in this study was the relation between the different zones of pulpal reaction to each other. The zones of PC covered the exposed pulp and induced the reaction. The zone of degeneration, although resulting from pulpal injury and chemical effects of the material protected the underlying vital tissues during early stage of healing. PC probably caused denaturation of adjacent cells because of the high surface $\mathrm{pH}$, mainly when freshly mixed.

Finally, the primary calcific bridge, as an early barrier between pulp tissues and the cavity allow the pulp to organize its cellular elements and form the permanent dentin bridge. In our study, new dentin bridge some distance from the material interface was found in one of the specimens 

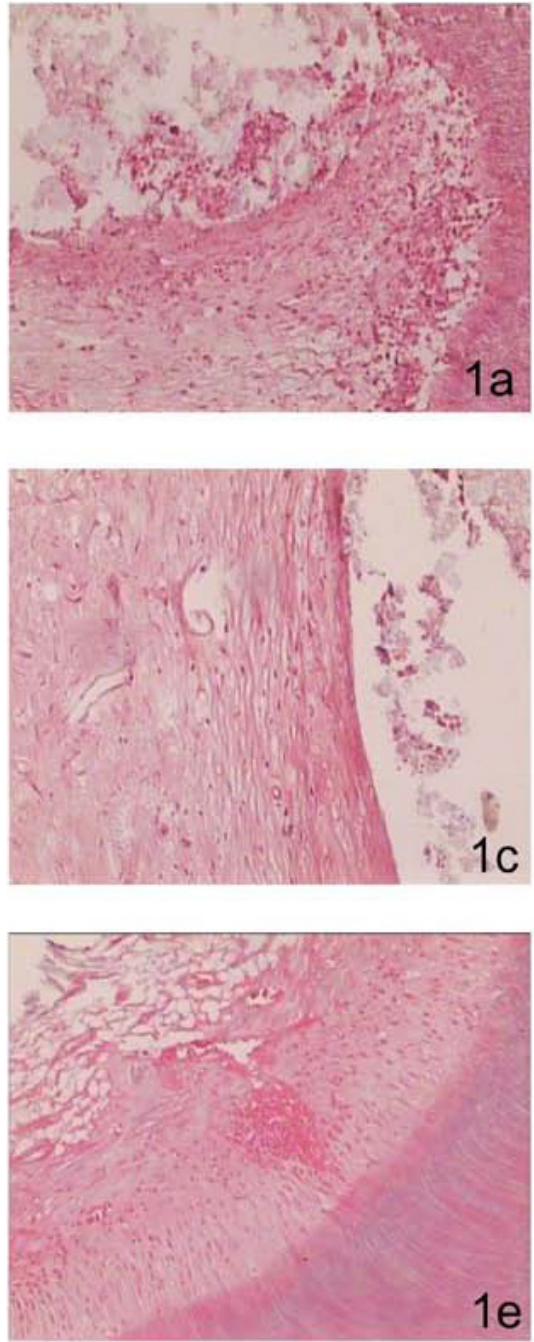
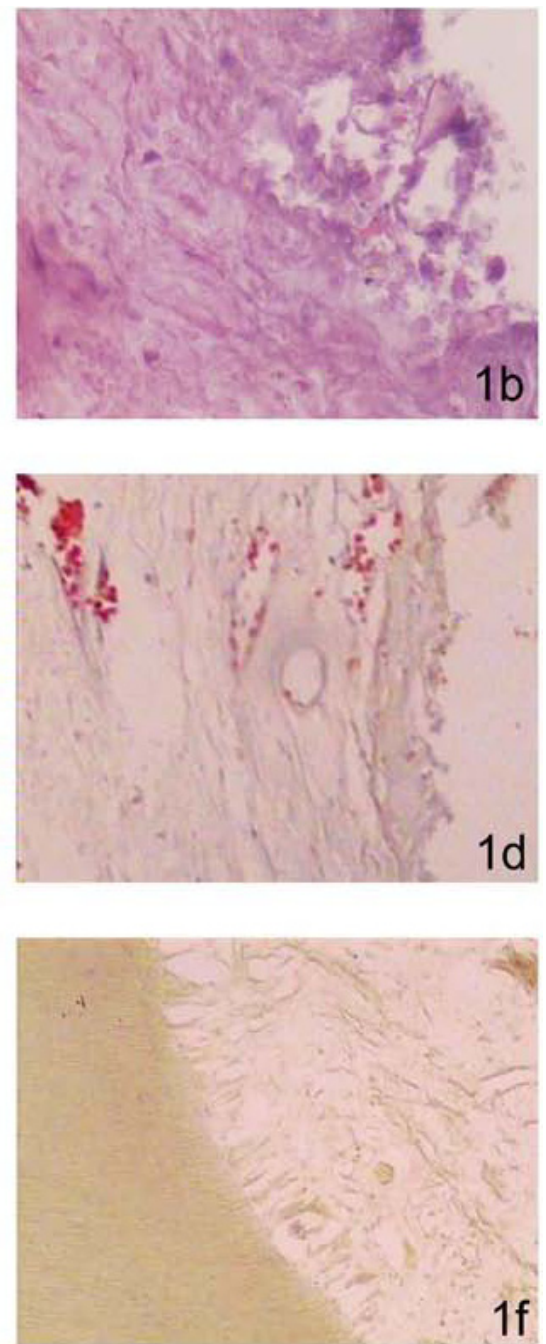

Fig. (1). 1a no dentin bridge formation was observed. Inflammatory cell response varied from soft to mild $\left(1^{\text {st }}\right.$ day, HE $\left.-100 X\right)$. In $1 \mathbf{b}$, a necrotic area could be observed underneath the exposure site $\left(7^{\text {th }}\right.$ day, HE $\left.-200 X\right)$. In 1c, no dentin bridge formation was observed, however, pulpal tissue exhibited organized collagenic deposition ( $7^{\text {th }}$ day, HE - 100X). In 1d, a dentin bridge distant from the interface pulp-capping material was present. Inflammatory cells were absent $\left(14^{\text {th }}\right.$ day, HE - 200X). In 1e, exposed tissue presented normal characteristics, with new odontoblast-like cells beneath the pulp-PC interface; inflammatory cell response was absent in all cases $\left(21^{\text {st }}\right.$ day, $\left.\mathrm{HE}-100 \mathrm{X}\right)$. In $\mathbf{1 f}$, absence of bacteria throughout the specimen was observed $\left(21^{\text {st }}\right.$ day, HE - 100X).

(2G3). The response to direct pulp capping with materials such as PC is the formation of a dentin barrier, resulting from the recruitment and proliferation of undifferentiated cells, which may be either stem cells or dedifferentiated and transdifferentiated mature cells. Once differentiated, the cells synthesize a matrix that undergoes mineralization. The extracelular matrix components can induce either reactionary dentin formation or formation of dentin barriers [10, 21].

This finding substantiates the results reported by Berman [22]. The presence of a dentin bridge under PC could be related to an inherent ability of the pulp to heal [3,22-24] regardless of the capping material $[3,6,15,17]$. However, no tubular dentin formation was observed after 21 days. Using calcium hydroxide, Demarco et al. [21] obtained the formation of 2-layered dentin bridges, an outer osteodentin region, and an inner tubular region, in 90 days. This tubular formation is a signal of maturation of the dentin [19].

Studies using germ-free animals have shown the importance of bacteria in the response of pulp tissue $[7,8]$. In this current study, no bacteria contamination was detected in any teeth. This means that the bacteriostatic action of $\mathrm{CP}$ was enough to reduce the number of viable bacteria near the pulp exposure. However, it is important to emphasize that the absence of bacterial staining did not mean sterility in those cases exhibiting inflammatory responses. A small number of bacteria can produce false-negative results $[25,26]$ or may be removed from the specimen during histological preparation $[3,20,22]$. Additionally, many bacteria may adhere to the restoration that is lost during the histological process [27].

The results of this study should be carefully evaluated because the capping procedure was accomplished in sound teeth. In most clinical scenarios, the pulp exposure frequently occurs by a carious process, in which the level of inflammation is much higher, and bacteria presence. The idea would be testing these procedures under the aforementioned condition to verify the reproducibility of the findings reported in this clinical evaluation. However, although the use of vital healthy teeth for this kind of study has limita- 
tions, it still has the benefit of standardization and can be regarded as acceptable in respect to material selection and handling.

\section{CONCLUSION}

Within the limitations of this current study, it is possible to conclude that after short-term histological evaluation:

1. Inflammatory cell response was absent in most of cases.

2. Dentin bridge was found in $10 \%$ of the specimens.

3 . Tissue under the exposure site presented the characteristics of normal pulp tissue, with new odontoblast-like cells located below the pulp/PC interface after 21 days.

In summary, the findings of our study support the idea that PC has potential to be used as a pulp capping material wich is capable of inducing short-term mineral pulp response. Further, long-term studies are necessary before unlimited clinical use can be recommended.

\section{ACKNOWLEDGEMENTS}

The authors are grateful to the Department of Oral Pathology and Semiology of School of Dentistry, UPE. This study was partially supported by CAPES.

\section{REFERENCES}

[1] Stanley HR. Pulp capping conserving the dental pulp - can it be done? Is it worth it? Oral Surg Oral Med Oral Pathol 1989; 68: 628-39.

[2] Brännström N, Nyborg $\mathrm{H}$. The presence of bacteria in cavities filled with silicate cement and composites resin materials. Sven Tandlak Tidskr 1971; 64: 149-55.

[3] Bergenholtz G, Cox CF, Lesche WJ, Syed SA. Bacterial leakage around dental restorations: its effect on the dental pulp. J Oral Pathol 1982; 11: 439-50.

[4] Cox CF, Keall C, Keall HJ, Ostro E, Bergenholtz G. Biocompatibility of surface-sealed dental materials against exposed pulps. J Prosthet Dent 1987; 57: 1-8.

[5] Cox CF, White KC, Ramus DL, Farmer JB, Snuggs HM. Reparative dentin: Factors affecting its deposition. Quintessence Int 1992; 23: $257-70$.

[6] Oguntebi BR, Heaven T, Clark AE, Pink FE. Quantitative assessment of dentin bridge formation following pulp-capping in miniature swine. J Endod 1995; 21: 70-3.

[7] Kakehashi S, Stanley HR, Fitzgerald RJ. The effects of surgical exposures of dental pulps in germ-free and conventional laboratory rats. Oral Surg 1965; 20: 340-49.

[8] Tsuji T, Takei K, Inoue T, Shimono M, Yamamura T. An experimental study on wound healing of surgically exposed dental pulps in germ-free rats. Bull Tokyo Dent Coll 1987; 28: 35-8.
[9] Wucherpfenning AL, Green D. Mineral trioxide vs. Portland cement: two biocompatible filling materials (abstract). J Endod 1999; 25: 308 .

[10] Holland R, de Souza V, Murata SS, et al. Healling process of dog dental pulp after pulpotomy and pulp covering with mineral trioxide aggregate or Portland cement. Braz Dent J 2001a; 12: 109-13.

[11] Holland R, de Souza V, Nery MJ, et al. Reaction of rat connective tissue to implanted dentin tube filled with mineral trioxide aggregate, Portland cement or calcium hydroxide. Braz Dent J 2001b; 12: 3-8.

[12] Estrela C, Bammann LL, Estrela CRA, Silva RS, Pecora JD. Antimicrobial and chemical study of MTA, Portland cement, calcium hydroxide paste, Sealapex and Dycal. Braz Dent J 2000; 11: 3-9.

[13] Torabinejad M, Hong CU, McDonald F, Pitt Ford TR. Physical and chemical properties of a new root-end filling material. J Endod 1995; 21: 349-53.

[14] Brown RC, Hopps HC. Staining of bacteria in tissue sections: a reliable Gram stain method. Am J Clin Pathol 1973; 60: 234-40.

[15] Cox CF, Subay RK, Suzuki S, Suzuki SH, Ostro E. Biocompatibility of various dental materials: Pulp healing with a surface seal. Int J period Rest Dent 1996; 16: 240-51.

[16] Akimoto N, Momoi Y, Kohno A, et al. Biocompatibility of clearfil AP-X system on nonexposed and exposed primate teeth. Quintessence Int 1998; 29: 177-88.

[17] Xie J, Powers JM, McGuckin RS. In vitro bond strenght of two adhesives to enamel and dentin under normal and contamined conditions. Dent Mater 1993; 9: 295-9.

[18] Kashiwada T, Takagi M. New restoration and direct pulp capping systems using adhesive composite resin. Bull Tokyo Med Den Univ 1991; 38: 45-52

[19] Schröder U. Effects of calcium hydroxide containing pulp-capping agents on pulp cell migration, proliferation, and differentiation. $\mathrm{J}$ Dent Res 1985; 65: 541-8.

[20] Kitasako Y, Shibata S, Tagami J. Migration and particle clearance from hard-setting $\mathrm{Ca}(\mathrm{OH}) 2$ and self-etching adhesive resin following direct pulp capping. Am J Dent 2006; 19(6): 370-5.

[21] Demarco FF, Tarquinio SBC, Jaeger MMM, Araújo VC, Matson E. Pulp response and cytotoxicity evaluation of 2 dentin bonding agents. Dent Mater 2001; 32: 211-20.

[22] Berman DS. Pulp healing following experimental pulpotomies in rat molars. J Dent Res 1958; 37: 229-42.

[23] Cox CF, Suzuki S. Re-evaluating pulp protection: Calcium hydroxide liners vs. cohesive hybridization. J Am Dent Assoc 1994; 125: 823-31.

[24] Cox CF, Suzuki S, Suzuki SH. Biocompatibility of dentin adhesives. J Can Dent Assoc 1995; 23: 35-41.

[25] Browne RM, Tobias RS. Microbial microleakage and pulpal inflammation: A review. Endod Dent Traumatol 1986; 2: 177- 83.

[26] Wijnbergen M, Van Mullem PJ. Effect of histological decalcifying agents on number and sustainability of Gram-positive bacteria. J Dent Res 1987; 66: 1029-31

[27] Accorinte MLR, Loguercio AD, Reis A, Muench A, Araújo V. Adverse effects of human pulps after direct capping with the different components from a total-etch, three-step adhesive system. Dent Mater 2005; 21: 599-607. 